\begin{tabular}{|c|c|c|c|c|c|c|}
\hline \multirow{4}{*}{ Impact Factor: } & ISRA (India) & $=3.117$ & SIS (USA) & $=0.912$ & ICV (Poland) & $=6.630$ \\
\hline & ISI (Dubai, UAI & $=0.829$ & РИНЦ (Russia) & $=0.156$ & PIF (India) & $=1.940$ \\
\hline & GIF (Australia) & $=0.564$ & ESJI (KZ) & $=5.015$ & IBI (India) & $=4.260$ \\
\hline & JIF & $=1.500$ & SJIF (Morocco) & $=5.667$ & & \\
\hline
\end{tabular}

\begin{tabular}{|c|c|}
\hline $\begin{array}{l}\text { SOI: } \underline{1.1 / 7} \\
\text { International } \\
\text { Theoretical } \mathbb{\&}\end{array}$ & $\frac{\mathrm{AS}}{\text { ientific Journal }} \frac{10.15863 / \mathrm{TAS}}{\text { Journal }}$ \\
\hline p-ISSN: 2308-4944 (print) & e-ISSN: 2409-0085 (online) \\
\hline Year: 2018 Issue: 12 & Volume: 68 \\
\hline Published: 17.12.2018 & ttp://T-Science.org \\
\hline
\end{tabular}

SECTION 32. Jurisprudence.
QR - Issue

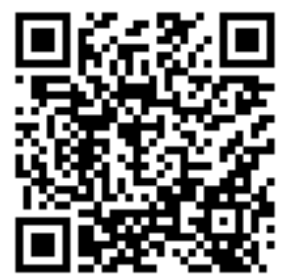

QR - Article

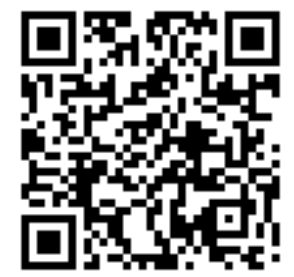

Iskandar Kamalovich Yusupaliev candidate of juridical science assistant professor of department "KandCE" of Osh governmental juridical institute Osh city of Kyrgyz Republic

\title{
THE CONCEPT OF HUMAN SECURITY IN THE CRIMINAL LAW OF KYRGYZ REPUBLIC
}

Abstract: This article discusses the concept of personal security in the criminal law of the Kyrgyz Republic. The author focuses on contemporary difficulties in finding models of the relationship between the state and the individual, which consist in establishing such a system and order in which the individual is provided with the opportunity to freely develop their potential and national goal.

Key words: law, concept, security, criminal law, person, state.

Language: Russian

Citation: Yusupaliev, I. K. (2018). The concept of human security in the criminal law of Kyrgyz republic. ISJ Theoretical \& Applied Science, 12 (68), 84-87.

Soi: http://s-o-i.org/1.1/TAS-12-68-17 Doi: crossef https://dx.doi.org/10.15863/TAS.2018.12.68.17

\section{КОНЦЕПЦИЯ БЕЗОПАСНОСТИ ЛИЧНОСТИ В УГОЛОВНОМ ПРАВЕ КЫРГЫЗСКОЙ РЕСПУБЛИКИ}

Аннотация: В данной статье рассматривается конщепщия безопасности личности в уголовном праве Кьргызской Республики. Основное внимание автором уделяется современным трудностям в поисках моделей взаимоотношения государства с личностью, которые заключаются в установлении такой системы и порядка, в которой личности обеспечивается возможность беспрепятственно развивать свой потенцииал и общчегосударственную ичель.

Ключевые слова: право, концепциия, безопасность, уголовное право, личность, государство.

\section{Introduction}

В XXI веке проблемы охраны прав человека стали занимать одну из важнейших мест и в общей теории государства и права, и в отраслевой юридической науке, процессуальной отрасли знаний. На современном этапе главная задача состоит в пересмотре и переработке имеющихся знаний, включении в цельную систему, освободив от сомнений, защитить от искажений [1]. При этом необходимо заметить, что основные современные трудности в поисках моделей взаимоотношения государства с личностью заключаются в установлении такой системы и порядка, в которой личности обеспечивается возможность беспрепятственно развивать свой потенциал и общегосударственную цель.

Особенности современного этапа развития Кыргызстана подчеркивают вопросы безопасности личности, которые приобретают все более заинтересованную важность. Права и свободы личности в Конституции Кыргызской Республики выступают провозглашенными высшей ценностью, признание, соблюдение и защита которых является обязанностью государств. Но данное провозглашение не является результатом претворения в жизнь вышеназванного положения [2]. Для этого важно разработка единых систем обеспечения безопасности личности, которые возможны на основе проведения комплексных анализов международно-правовой нормы и совершенствования действующих нормативных правовых актов Кыргызстана.

\section{Materials and Methods}

Основными элементами содержания Концепции охраны прав личности в Кыргызской Республике как систем принципа и стандарта являются нижеследующие положения: 


\begin{tabular}{|c|c|c|c|c|c|c|}
\hline \multirow{4}{*}{ Impact Factor: } & ISRA (India) & $=3.117$ & SIS (USA) & $=0.912$ & ICV (Poland) & $=6.630$ \\
\hline & ISI (Dubai, UAI & $=0.829$ & РИНЦ (Russia) & $=0.156$ & PIF (India) & $=1.940$ \\
\hline & GIF (Australia) & $=0.564$ & ESJI (KZ) & $=5.015$ & IBI (India) & $=4.260$ \\
\hline & JIF & $=1.500$ & SJIF (Morocco) & $=5.667$ & & \\
\hline
\end{tabular}

1. обеспечение безопасности личности в уголовном праве выступает высшей ценностью (Конституции КР, Преамбула к Уставу ООН, Преамбула к Уставу Всеобщей декларации прав человека и др.);

2. обеспечение безопасности личности в уголовном праве должна реализоваться системами международного и внутригосударственного гарантии прав и свобод личности;

3. посредством обеспечения концепция безопасности личности в уголовном праве реализуется равенство прав и свобод личности;

В результате неудовлетворения потребностей человека в правовой защите наступают нестабильные состояния, социальные напряженности, ухудшения общей криминальной обстановки. В связи с этим государства должны быть заинтересовано в прочных и эффективных гарантиях обеспечения безопасности личности. Для достижения целей повышения эффективности обеспечения безопасности личности, в первую очередь необходимы в этом направлении уделить внимания уголовному законодательству.

Криминологической ситуацией в стране актуализируется проблема обновления норм уголовного законодательства в соответствии с международным и национальным стандартом в области прав человека.

Важно противопоставления внутренне согласованных и криминологически обоснованных систем уголовно-правовых средств борьбы с преступлениями против личности, в странгулировании радикально-репрессивной и радикально-либеральной модели борьбы с преступностью.

В реализации основных направлений в создании таких систем на основах требовании социальной необходимости и научной обоснованности необходимо согласование положений уголовного, конституционного и международного права с целью установления юридической гарантии безопасности личности, осуществления процесса криминализации деянии, дифференциации уголовной ответственности и индивидуализации наказания [5].

Вопросы правовой безопасности человека не могут быть новой и не носят фрагментарный характер, и в этой связи необходимо заключить, что проблема анализа уголовно-правового средства обеспечения безопасности личности, находится в центре внимания научной общественности [3]. До настоящего времени стратегический вопрос уголовной политики государства в части охраны и защиты интересов личности все еще остается недостаточно изученным и определяет комплекс общественных отношений, возникающих в данном процессе. Во время разработки стратегий уголовной политики по обеспечению безопасности личности, ее основных прав и свобод нужно отторгнуть спорадическое отношение путем применения современных методов познания, в том числе диалектических методов, с учетом соблюдений требования обеспечения следующих условий: объективность, всесторонность, комплексность и конкретность познаний.

Гарантии обеспечения безопасности человека выступают одними из ключевых моментов. В современное время аксиоматично понимаются положения, что в подлинно правовом государстве человек представляет собой высшую социальную ценность, а вопрос обеспечения его безопасности являются смыслом и целью общественного развития.

В соответствии с ч. 1 ст. 2 УК КР, «целью Уголовного кодекса Кыргызской Республики является охрана личности, прав и свобод граждан». Данная норма, по утверждению некоторых ученых, ориентирована на подчинения иерархии интереса, охраняемого нормой уголовного права, гуманистической ценности и включают в себя требование максимально полного отражения в этом положении приоритетов прав и свобод человека и гражданина.

В советское время в соответствии с концепцией безопасности человека основной акцент ученого уделялось вопросам обеспечения внешней безопасности социалистических обществ от угрозы со стороны враждебных капиталистических стран [6]. Отдельная личность, должен был рассматриваться не в качестве самостоятельных субъектов права, а не в качестве субъектов, которые подлежат защите социумом [4].

Нижеследующие документы, составляют международно-правовые основы обеспечения безопасности человека: Устав ООН (1945г.), Всеобщая декларация прав человека (1948г.), Международный пакт о гражданских и политических правах (1966 г.), Международный пакт об экономических, социальных и культурных правах (1966 г.) и др. Международный документ, содержит положение, определяющее государства элементами обеспечения любым лицам права и свободы которых нарушены, эффективнее средства правовой защиты, даже если эти нарушения были совершены лицом, действовавшим в официальном качестве.

Кроме этого рассматривается нормативноправовой документы, отражающий предупреждение и пресечение посягательства на безопасность личности, ее основные права и свободы: Международную конвенцию о 


\begin{tabular}{|c|c|c|c|c|c|c|}
\hline \multirow{4}{*}{ Impact Factor: } & ISRA (India) & $=3.117$ & SIS (USA) & $=0.912$ & ICV (Poland) & $=6.630$ \\
\hline & ISI (Dubai, UAE & $=0.829$ & РИНЦ (Russia) & $=0.156$ & PIF (India) & $=1.940$ \\
\hline & GIF (Australia) & $=0.564$ & ESJI (KZ) & $=\mathbf{5 . 0 1 5}$ & IBI (India) & $=4.260$ \\
\hline & JIF & $=1.500$ & SJIF (Morocco) & $=5.667$ & & \\
\hline
\end{tabular}

ликвидации всех форм расовой дискриминации (1965 г.), Конвенцию о предупреждении геноцида и наказания за него (1948 г.), Конвенцию о пресечении преступления апартеида и наказании за него (1973 г.) и др.

Роль и значение международно-правовых актов в формировании единых систем обеспечения безопасности личности в государстве, заключаются в том, что международный документ закрепляет перечень основных прав и свобод личности, составляющих объект безопасности; определяет обязанности государств-участников признавать, обеспечивать и защищать жизненно важного блага человека, а равно закладывает правовую основу реализации права личности на безопасное существование [7].

Уголовное законодательство, основывается принципами и нормами международного законодательства и ориентируется всесторонней охраной личности, ее прав и интересов. Исходя из принципов гуманизма, УК КР определяют круг наиболее важных для человека прав и свобод, конструируют уголовно-правовой запрет на совершение преступления против личности и дифференцируют уголовную ответственность.

В ходе проведенных анализов уголовноправовых механизмов обеспечения безопасности личности в уголовном праве Кыргызской Республики на основе диалектических методов выявлены слежующие аспекты в установлении понятия «безопасность человека»: безопасность как состояние; безопасность как деятельность; безопасность как система. Они направляют действия в ходе исследований для обеспечения безопасности личности в уголовном праве Кыргызской Республики и дают ориентиры в поиске аргументов.

Важно выделить следующие группы чтобы определить понятия средства охраны в сфере обеспечения безопасности личности: уголовноправовые запреты и отношения, направленные на предупреждение преступления против основных прав и свобод человека и гражданина; нормы и правоотношения, осуществляющие восстановление нарушенного преступлением интереса человека.

Потенциалами восстановления нарушенных прав объясняются, что государствами предоставляются потерпевшим право на компенсацию причиненного вреда, расширяются сферы свободы личности в уголовно-правовом отношении и стимулируются реститутивные отношения между виновными и потерпевшими и специфический по характеру связь потерпевших и государства [8].

Для защиты своего права каждый человек вправе на причинение вреда посягающим лицам в состоянии необходимой обороны. То есть уголовным законом предусматривается право обороняющегося лица. К сожалению, на практике возникают проблемы при установлении критериев меры самообороны в отношении определении его правомерности (в превышении меры самообороны, которые повлекли причинения смерти или тяжкого вреда здоровью).

В современное время констатируются, что Уголовные нормы Кыргызской Республики противоречиво и не в полной мере не могут использовать свои предупредительные потенциалы для обеспечения безопасности личности. Основными причинами такой ситуации являются отсутствие единых подходов в делах установления гносеологических и правовых сущностей права и свободы человека.

Проблемы защищенности личности играют одну из центральных в работе законотворческих и правоприменительных органов, а реальные условия криминологической обстановки показывают об обратном: государственные институты не справляются с обеспечением безопасности человека [9].

Основной причиной кризиса уголовной политики государства в сфере обеспечения безопасности личности выступает не только социальное условие (росты напряженности в обществах, проведения социальноэкономических преобразования, низкий уровень правосознания граждан и др.), но и фактор организационного характера (отсутствия единых государственных концепций безопасности личности, а равно научно-обоснованной рекомендации по их практической реализации; несогласованные мероприятий в деятельности правоохранительных структур и др.) [10].

\section{Conclusion}

Важно подчеркнуть, что в области международной и региональной безопасности дестабилизирующий элемент и фактор неопределенности выступает основным проблемным элементом. Формирования эффективных систем безопасности личности остаются на повестке дня всех государств Центральной Азии. Поэтому назревает настоятельная необходимость в диверсификациях политики партнерства в зарубежных странах с выходом за пределы существующей структуры безопасности. Ощущаются потребности в постоянно действующих площадок, где заинтересованная сторона могла бы сотрудничать в вопросе безопасности личности. В Кыргызстане располагаются все условия становления регионального центра принятия решения в этой области, где может базироваться центральноазиатские организации аналогичные ОБСЕ, которые позволят с успехом решать проблему безопасности в Европе и мире в 70-х годах двадцатого века. 


\begin{tabular}{|c|c|c|c|c|c|c|}
\hline \multirow{4}{*}{ Impact Factor: } & ISRA (India) & $=3.117$ & SIS (USA) & $=0.912$ & ICV (Poland) & $=6.630$ \\
\hline & ISI (Dubai, UAI & $=0.829$ & РИНЦ (Russia) & $=0.156$ & PIF (India) & $=1.940$ \\
\hline & GIF (Australia) & $=0.564$ & ESJI (KZ) & $=5.015$ & IBI (India) & $=4.260$ \\
\hline & JIF & $=1.500$ & SJIF (Morocco) & $=5.667$ & & \\
\hline
\end{tabular}

Кыргызстан, является одновременно членом нескольких существующих систем безопасности (ОДКБ, ШОС и др.), и должен активно продолжать работать в отстаивании собственного интереса безопасности при сотрудничествах с этими организациями. Данные сотрудничества создают множество благоприятных возможностей, но и выявляют ряд проблемных моментов, особенно, когда речь идет о сотрудничестве $\mathrm{c}$ международной структурой безопасности, имеющее различные стратегические видения и интерес, метод и состав участников. Этим предопределяется динамичность характера отношений с ним, меняющийся в соответствии с изменением силы проявлений той или иной угрозы и вызова безопасности граждан Кыргызстана, а также при выборах средства и метода защиты национального интереса в данных исторических моментах.

В указанной области важно проведение исследовательских работ посредством применений надлежащих методов, которые могут предопределять нормативно-правовые базы уголовного права Кыргызской Республики и будут обеспечивать безопасность личности и регулировать данный процесс.

\section{References:}

1. (2013). Kontseptualnyie voprosyi reformirovaniya ugolovnogo sudoproizvodstva Kyirgyizskoy Respubliki. Stenogramma ekspertnogo foruma ot 22 aprelya $2013 \mathrm{~g}$.

2. (2006). «Kontseptsiya etnicheskoy politiki i konsolidatsii obschestva», proekt odobrennyiy na VII Kurultae ANK.

3. Shadrin, O. Y., \& Koombaev, A. A. (2012). Mezhdunarodnoe sotrudnichestvo $v$ borbe $v$ prestupnostyu. Uchebnoe posobie, Bishkek: ID «Altyin Tamga».

4. Koombaev, A. A. (2014). Polozhenie lichnosti v ugolovnom sudoproizvodstve. dissert. po pravu.

5. Koombaev, A. A. (2012). Polozhenie lichnostiv ugolovnom sudoproizvodstve. pravovyie $\mathrm{i}$ nravstvennyie aspektyi. Obrazovanie. Nauka. Nauchnyie kadryi.
6. Bastryikin, L. I. (1986). Vzaimodeystvie sovetskogo ugolovno-protsessualnogo $i$ mezhdunarodnogo prava. (p. 112). L.

7. Brusnitsyin, L. V. (1999). Pravovoe obespechenie bezopasnosti lits, sodeystvuyuschih ugolovnomu pravosudiyu. (p.109). M.: Spark.

8. Koblikov, A. S. (2003). Yuridicheskaya etika: Ucheb. dlya vuzov. 2-e izd., s izm. (p.176). M.: Norma.

9. Kudryavtsev, V. N. (1982). Pravovoe povedenie: norma i patologiya. (p.287). M..

10. Lupinskaya, P. A. (1972). Zakonnost $i$ obosnovannost resheniy $v$ ugolovnom sudoproizvodstve. (p.79). M.. 